\title{
Raman and FT-IR Spectroscopy investigation the cellulose structural differences from bacteria Gluconacetobacter sucrofermentans during the different regimes of cultivation on a molasses media
}

Nelli Atykyan ( $\sim$ kistig2@yandex.ru )

National Research Mordovia State University https://orcid.org/0000-0002-4647-8128

Victor Revin

National Research Mordovia State University

Vitalina Shutova

National Research Mordovia State University

Original article

Keywords: bacterial cellulose, Gluconacetobacter sucrofermentans, FT-IR spectroscopy

Posted Date: May 8th, 2020

DOI: https://doi.org/10.21203/rs.3.rs-16017/v2

License: (1) (i) This work is licensed under a Creative Commons Attribution 4.0 International License.

Read Full License

Version of Record: A version of this preprint was published at AMB Express on May 3rd, 2020. See the published version at https://doi.org/10.1186/s13568-020-01020-8. 


\section{Abstract}

Raman and Fourier Transform Infrared (FT-IR) spectroscopy was used for investigation of structural differences of bacterial celluloses (BC), obtained by cultivation native and immobilized cells of Gluconacetobacter sucrofermentans during static and dynamic regimes of cultivation on a molasses media. It was found that the Raman and FT-IR spectra could characterized the groups of the cellulose molecules. The culturing bacterial cellulose in the presence of results in an increase of crystalline and it increased during cultivated on a molasses media with the addition of $1.5 \%$ ethanol $-75.62 \%$. The degree of $\mathrm{BC}$ crystallinity increased during dynamic regime of cultivation is higher than under static regime one. The maximal BC content was observed when $0.5 \%$ ascorbic acid was added to the cultivation medium with molasses and native cells. It was found, the degree of BC crystallinity during static regime cultivation on a molasses medium with ethanol, increased significantly to $73.5 \%$, and during dynamic regime $75.6 \%$. So, in this study, the changes of the bacterial cellulose conformation of were revealed during bacterial cultivation in a medium containing molasses in various cultivation modes.

\section{Introduction}

Bacterial cellulose (BC) is carbohydrates produced by Komagataeibacter, Gluconacetobacter, Enterobacter, Pseudomonas, Achromobacter, Alcaligenes, Aerobacter, Azotobacter, Agrobacterium, Burkholderia, Dickeya, Escherichia, Rhizobium, Salmonella, and Sarcina with unique biotechnological properties (the finest porosity and mechanical strength) and wide range of applications (promising material for medicine, industry and technology) (Klemm et al. 2001; Zhu et al. 2001; Maneerung et al. 2008; Castro 2013; Lee et al. 2014; Augimeri et al. 2015; Cauerhff, Cacicedo et al. 2015; Rastogi et al. 2018). Important, the plants cellulose formed complex with other compounds such as hemicelluloses, lignin etc but BC is pure cellulose and does not contain these components (Fu et al. 2013; Augimeri et al. 2015). BC is biodegradable and non-toxic, has a high crystallinity, but is not completely crystalline, and a high degree of polymerization (Schenzel, Fischer 2004; Hsieh et al. 2008; Kaewnopparat et al. 2008; Szymańska-Chargot et al. 2011). The BC synthesis depends on by number of experimental factors: (1). the culture medium composition, namely: sources of carbon, nitrogen, micro- and macro elements; (2). the cultivation conditions (temperature, $\mathrm{pH}$, dissolved oxygen concentration, cultivation method, etc.) (Matsuoka et al. 1996; Ramana et al. 2000; Thompson, Hamilton 2001; Chawla et al. 2009; Pa'e et al. 2011); (3) not only glucose and sucrose are used for BC synthesis, but fructose, maltose, xylose, starch, glycerin, ethanol and other sources of carbon can be used (Hestrin, Schramm 1954; Park et al. 2003; Hungund et al. 2013). Concerning, the carbon sources are often the most expensive components of the culture medium, so modern biotechnology offers to use sugar-containing waste from food industries, such as molasses, DDGS, whey (Keshk et al. 2006; Kongruang 2008; Coban, Biyik 2011; Zeng et al. 2011; Guo et al. 2013; Rani, Appaiah 2013; Wu, Liu 2013; Jozala et al. 2014; Lin et al. 2014; Kiziltas et al. 2015). At the same time, a change in the composition of the medium and the condition of cultivation leads to an increase/decrease yield of the $\mathrm{BC}$, but to modification of its structure. The $\mathrm{BC}$ properties depend on the degree of cellulose crystallinity. The crystalline domains in $\mathrm{BC}$ are of very limited size and are mixed with 
noncrystalline regions. The latter is important because the plant celluloses and $\mathrm{BC}$ have the same molecular structure, but differ in crystalline structures connected with its crystalline structure polymorphs (cellulose I-IV): in nature (cellulose I); cellulose II is synthesized by bacteria or algae. In addition, cellulose II and cellulose III and IV can be obtained from cellulose I by chemical treatment (Brett, Waldron 1990; Szymańska-Chargot et al. 2011). The cellulose crystalline domains are divided by the non-crystalline cellulose regions and the ratio of crystalline and non-crystalline regions determine some properties of cellulosic fibrils, for example tensile strength (Szymańska-Chargot et al. 2011). The ratio of crystalline regions to total fibrils of cellulose (the crystallinity index) can be investigated by a variety of methods like X-ray diffraction, solid-state 13C-NMR or wide-angle X-ray scattering experiments (Zugenmeier 2008). This method can be supplemented by infrared and Raman spectroscopy, which are the simplest and the least time consuming methods of BC crystallinity index determination (Schenzel et al. 2005). An obvious disadvantage of this method is that it can give only relative crystallinity index values because the spectrum consists of contributions from both amorphous and crystalline regions

The purpose of this work was a comparative analysis by the method of FTIR and Raman spectroscopy of BC structure obtained by cultivation native and immobilized cells of Gluconacetobacter sucrofermentans during static and dynamic regimes of cultivation on a molasses media.

\section{Materials And Methods}

\section{Microorganisms and culture conditions}

The studies object was the bacteria cellulose from the Gluconacetobacter sucrofermentans VKPM B11267, selected at the Department of Biotechnology, Bioengineering and Biochemistry National Research Mordovia State University and was deposited in Russian National Collection of Industrial Microorganisms. Bacterial culture was maintained on medium of Hestrin - Shramm (Hestrin, Schramm 1954) at the $4^{\circ} \mathrm{C}$ after growing them for 3 days at $28^{\circ} \mathrm{C}$. For the cultivation of producers used nutrient medium of the following composition $(\mathrm{g} / \mathrm{l})$ :

\section{1. medium of Hestrin-Shramm}

2. medium with molasses ( $24 \mathrm{~g} / \mathrm{I}$ in terms of sucrose)

3. medium with molasses ( $36 \mathrm{~g} / \mathrm{I}$ in terms of sucrose)

4. medium with molasses ( $48 \mathrm{~g} / \mathrm{I}$ in terms of sucrose)

5. medium with molasses ( $36 \mathrm{~g} / \mathrm{I}$ in terms of sucrose) with addition $1,5 \%(\mathrm{v} / \mathrm{v})$ ethanol.

6. medium with molasses ( $36 \mathrm{~g} / \mathrm{I}$ in terms of sucrose) with addition $1,5 \%(\mathrm{v} / \mathrm{v})$ glycerol.

7. medium with molasses ( $36 \mathrm{~g} / \mathrm{I}$ in terms of sucrose) with addition $0,5 \%(\mathrm{w} / \mathrm{v})$ ascorbic acid

8. medium with molasses ( $36 \mathrm{~g} / \mathrm{I}$ in terms of sucrose) with addition $0,5 \%(\mathrm{w} / \mathrm{v})$ lignosulfonate

The initial culture for the preparation of the inoculum was a culture on a mown agar medium. It was washed and suspension was used for the inoculum preparation. A suspension of microorganisms (10 
$\mathrm{ml}$ ) were seeded in the flasks with $100 \mathrm{ml}$ of medium. The inoculum was grown on an orbital shaker $20 / 60$ incubator shaker (Biosan, Latvia) at $250 \mathrm{rpm}$ and a temperature of $28^{\circ} \mathrm{C}$ for one day.

The dynamic regime of bacteria cultivation was carried out in bioreactors BIOSTAT A plus (Sartorius, Germany) with mechanical (200 rpm) and air ( 1 I per 1 I medium per minute) mixing. Experimental flasks were seeded with $10 \%$ inoculum and placed on an ES-20/60 shaker incubator (Biosan, Latvia) at $200 \mathrm{rpm}$ for 3 days. Bioreactors were also inoculated with 10\% inoculum and cultured for $3-5$ days. The static regime of bacteria cultivation was carried out in flat containers: a suspension of microorganisms (50 ml) was seeded with $500 \mathrm{ml}$ of medium and then left in static conditions.

To remove cells and medium components $\mathrm{BC}$ was treated with a $0.1 \mathrm{M} \mathrm{HCl}$ at $85^{\circ} \mathrm{C}$ for 30 minutes and 3 times washed with distilled water. After $\mathrm{BC}$ was treated with $1 \mathrm{~N} \mathrm{NaOH}$ at $80^{\circ} \mathrm{C}$ for 30 minutes and also 3 times washed with distilled water. The BC was boiled in water for 10 minutes and the amount of bacterial cellulose was determined by the gravimetric method.

\section{FTIR spectroscopy of bacterial cellulose samples}

The BC FT-IR spectra were collected on a Fourier spectrometer model IRPrestige-21 (Shimadzu, Japan). The purified $\mathrm{BC}$ was prepared to additional drying to constant weight at $60^{\circ} \mathrm{C}$. The samples $(2-4 \mathrm{mg})$ were fixed (in an agate mortar with $0.12 \mathrm{~g}$ of $\mathrm{KBr}$ ) and compressed (laboratory hydraulic press PGR-10 at a pressure of 210 bar for 1 minute). The spectra were collected over the range $4000-650 \mathrm{~cm}^{-1}$. For each material, five samples under the same conditions were examined. For each sample, 200 scans were averaged with a spectral resolution of $4 \mathrm{~cm}^{-1}$. Then for a given material, a final average spectrum was calculated. These spectra were normalized to 1.0 at $1,136 \mathrm{~cm}^{-1}$ (COH stretching vibration). Baseline corrections were obtained on Omnic Software (Thermo Scientific).

It is known that two IR peaks around 750 and $710 \mathrm{~cm}^{-1}$ are characteristic for triclinic (Ia) and monoclinic unit $(I \beta)$ allomorphs, respectively. The relative proportion of cellulose $I \beta$ to la allomorph could be calculated by integrating the absorption bands near 710 and $750 \mathrm{~cm}^{-1}$ and the percentage of $I \beta$ could be obtained.

\section{Raman spectroscopy of BC samples}

Before Raman spectrum registration the $\mathrm{BC}$ was dried to constant mass The bacterial cellulose films was applied on a microscope glass. Raman spectra were collected on a Raman - dispersive spectrometer inVia by Renishaw (UK), based on a LeicaDM 2500 microscope with laser $532 \mathrm{~nm}$ and maximum power $10 \mathrm{~mW}$. The spectra were recorded over the range $1700-850 \mathrm{~cm}^{-1}$ using an operating spectral resolution of $2.0 \mathrm{~cm}^{-1}$ of Raman shift. Spectra were taken with $5 \mathrm{~s}$ exposure and $100 \mathrm{~mW}$ laser power output. These spectra were normalized to 1.0 at $2900 \mathrm{~cm}^{-1}$. It was shown that the intensity of RS peaks at 1462 and $1481 \mathrm{~cm}^{-1}$, which correspond to $\mathrm{CH} 2$ bending, relates to crystalline/amorphous proportions in cellulosic molecules. The higher the peak at $1,481 \mathrm{~cm}^{-1}$, the higher the cellulose crystallinity degree is too. In the 
case when amorphous cellulose predominates over crystalline one, there is only evidence of a broad peak at $1,462 \mathrm{~cm}^{-1}$. On this basis one can estimate the crystalline index by counting a relative percentage amount of crystalline fraction in a cellulosic sample.

\section{X-Ray diffraction (XRD)}

X-Ray diffraction (XRD) was performed using "Empyrean PANalytical" X-ray diffractrometer in the filtered radiation of a copper anode $(\lambda=0.15418 \mathrm{~nm}, 40 \mathrm{kV} \mathrm{b} 30 \mathrm{~mA})$ in the range of angles $2 \theta$ from $10^{\circ}$ to $60^{\circ}$. The measurements were carried out using a two-coordinate detector Pixcel $3 \mathrm{~d}$ that operated in the linear scanning mode ( 255 pixels per strip) with a resolution of 0.013 degrees / strip. The sample of bacterial cellulose was a gel film of bacterial cellulose dried at $60^{\circ} \mathrm{C}$. To exclude additional scattering from the substrate, a standard holder for strong films was used. Thus, the contribution to the total scattering was determined only by scattering by air. Cellulose samples have a layered fiber structure in which the fibers lie mainly in the plane of the film. In this regard, the measurements were carried out in two setups: "reflection" and "transparency".

\section{Scanning electron microscopy}

The BC was analyzed by scanning electron microscope TM 3000, manufactured by HITACHI (Japan) with the microanalysis system SwiftED3000, manufactured by Oxford Instruments (UK). Microscope resolution was of the order of $50 \mu \mathrm{m}$ (a magnification of 1600X), depth resolution $-0.5 \mathrm{~mm}$. Measurements of the $\mathrm{BC}$ were taken in a high vacuum of the order of $10^{-2}-10^{-3} \mathrm{~Pa}$, at an accelerating voltage of $15 \mathrm{kV}$. To pretreat the sample dry method of preparation was used.

\section{Gluconacetobacter sucrofermentans cells immobilization}

The cell biomass obtained by aseptic centrifuging at $5000 \mathrm{rpm}$ during 10 minutes was mixed at room temperature in an $8 \%$ solution of polyvinyl alcohol prepared. The suspension was distributed, frozen at $-20^{\circ} \mathrm{C}$ and kept in the frozen state for 17 hours. The pellets were thawed at $8^{\circ} \mathrm{C}$ for 3 hours.

\section{Statistical processing of results}

Statistical treatments of experimental data carried out by the method of variation statistics on a personal computer using Microsoft Excel.

\section{Results}

During the bacteria cultivation on HS medium the content of BC was $1.25 \mathrm{~g} / \mathrm{I}$ during static and dynamic regimes (Figure 1). Then the bacteria cultivation was carried out on a medium with molasses. It was found that during cultivation on molasses $(50 \mathrm{~g} / \mathrm{l})$ medium the $\mathrm{BC}$ contents was increased in static regime than in dynamic ones $(1.56 \mathrm{~g} / \mathrm{l})$. When the molasses concentration changes to $75 \mathrm{~g} / \mathrm{l}$ the BC contents was $2.34 \mathrm{~g} / \mathrm{l}$ (in static regime) and $2 \mathrm{~g} / \mathrm{l}$ (in dynamic regime) and increasing of the molasses concentration did not have a positive effect on BC contents. In next experiments we used $1.5 \%$ ethanol 
with $75 \mathrm{~g} / \mathrm{l}$ molasses. In this case, the BC output during static regime was $2.86 \mathrm{~g} / \mathrm{l}$, and in dynamic - 1.98 $\mathrm{g} / \mathrm{l}$ (Figure 1). In next stages of investigation as an additive in molasses medium was used ascorbic acid $(0.5 \% \mathrm{w} / \mathrm{v})$. The cellulose production during static regime was $2.48 \pm 0.12 \mathrm{~g} / \mathrm{I}$, and in during dynamic one - $3.73 \pm 0.18 \mathrm{~g} / \mathrm{l}$. (Figure 1 )

According this investigation general idea in next experiments was to study the changes of the degree of $\mathrm{BC}$ crystallinity using IR and RS. It has been shown that no changes in the of $\mathrm{BC}$ degree of crystallinity in HS medium at different conditions (Figure 2). It was found, the degree of $\mathrm{BC}$ crystallinity during static regime cultivation on a molasses medium with ethanol, increased significantly to $73.5 \%$, and during dynamic regime - $75.62 \%$ (Figure 2). During static regime cultivation the bacteria on molasses medium with the ascorbic acid, the BC degree of crystallinity was $51.40 \%$ (lower than in the control), and during dynamic regime $-59.92 \%$ (approximately at the same level as in the control).

In next experiment the BC FTIR spectrum at the different of cultivation medium composition during static regime was studied. The BC FTIR spectra in these experiments does not changes. Figure 3 shows the FTIR spectra of BC obtained by bacteria cultivation at static and dynamic regime on a molasses and HS medium with the addition of ethanol and ascorbic acid. As we can see the FTIR spectra are identical there is only a slight shift of the peak correlated with the valence vibrations of the $\mathrm{OH}$ groups in $\mathrm{BC}$ obtained on molasses medium with addition of ascorbic acid.

In next experiments was used immobilized cells of bacteria. Our investigation was demonstrated that during the static cultivation regime using immobilized cells in a cryogel the $B C$ is formed film on the surface of the medium (Figure 4A), and during dynamic regime - in form of "stars" in small cellulose flakes (Figure 4B). Using the immobilized cells, semi-continuous cultivation of the BC was carried out at static and dynamic regimes. It was found that at the first period of cultivation during static regime, the maximal BC contents was $2.12 \pm 0.12 \mathrm{~g} / \mathrm{l}$., but during the second and third period, it decreased to $1.99 \pm$ $0.02 \mathrm{~g} / \mathrm{l}$, and $0.80 \pm 0.10 \mathrm{~g} / \mathrm{l}$, respectively (Figure 5). During the dynamic regime of the cultivation at the first and second stage, the BC output does not change $(2.59 \pm 0.13 \mathrm{~g} / \mathrm{l}$.), but, there BC contents significant decreased in the third period (to $1.22 \pm 0.01 \mathrm{~g} / \mathrm{l}$ ). Using the FTIR the molecular structure of BC obtained with help of immobilized cells during dynamic and static culture conditions regime were the same (Figure 6). In next experiment we use RS for studies changes of the degrees of crystallinity BC production with the help of immobilized Gluconacetobacter sucrofermentans cells; the degree of crystallinity of the BC was approximately the same 66\% (Dynamic regime) and 52.26\% (Static regime). A typical X-ray diffractogram obtained from the $\mathrm{BC}$ sample demonstrated two characteristic clearly resolved peaks (Figure 7). SEM images of dried samples of flakes of bacterial cellulose was received (Figure 8). It can be seen from the image that, as in the case of synthesis by native bacteria, during synthesis by an immobilized culture, $\mathrm{BC}$ is formed in the form of flakes consisting of interweaving of thinner fibers.

So, in the course of this study, the changes of the bacterial cellulose conformation of were revealed during bacterial cultivation in a medium containing molasses in various cultivation modes. 


\section{Discussion}

During the bacteria cultivation on HS medium the yields of BC was small as during static also in dynamic regime which may be due to the accumulation of gluconic acid in the process of utilization of glucose by G. sucrofermentans (Masaoka et al. 1993). Moreover, HS medium includes expensive components as glucose, yeast extract, peptone, etc. In this reason the next experiments the bacteria cultivation was carried out on a cheap medium with molasses, which as was shown has a positive effect on the synthesis of BC due to the polyphenols and sucrose (Coban, Biyik 2011; Zeng et al. 2011). Molasses is traditionally used for cultivation of bacteria producing various polysaccharides - alginate (Revin et al. 2018), levan (Revin et al. 2016), dextran (Revin, Shutova 2015) and others. Also it is known that during bacteria cultivation in media with molasses, the changes of reducing sugars content leads to a decrease the gluconic acid production (Zeng et al. 2011). In our experiments changing HS medium on molasses (75 g/l) increased the yield of BC more than 1,5 time and 2 time in molasses medium with ethanol. Probably adding ethanol to the medium increased cellulose production and decreased the numbers of mutants non-cellulose producing cells (Park et al. 2003). Also was shown that BC synthesis increases with the addition of antioxidants, for example, vitamin C (Keshk $2014 \mathrm{a}, \mathrm{b}$ ). The yield of bacterial cellulose in molasses medium with adding $0.5 \%$ ascorbic acid increased 3 time approximately at the yields in the control HS medium.

The BC RS peaks at $1462 \mathrm{~cm}^{-1}$ and $1481 \mathrm{~cm}^{-1}$ correspond to $\mathrm{CH}_{2}$ bending, relates to crystalline/amorphous proportions in some cellulosic molecules (Schenzel et al. 2005). It was observed that a higher peak at $1481 \mathrm{~cm}^{-1}$ corresponds with a higher degree of crystallinity. It has been shown that no changes in the of $\mathrm{BC}$ degree of crystallinity in HS medium at different conditions but on a molasses medium with ethanol, crystallinity was increased significantly to $75.62 \%$ (Dinamic regime).

The FTIR spectrum peak in the region of $3347 \mathrm{~cm}^{-1}$ characterizes the stretching vibrations of $\mathrm{OH}$ groups, the peak in the region of $2897 \mathrm{~cm}^{-1}$ indicates the stretching vibrations of the $\mathrm{C}-\mathrm{H}$ groups and $1662 \mathrm{~cm}^{-1}$ is the region of deformational vibrations of $\mathrm{OH}$-groups of bound water. The BC FTIR spectrum peaks in the range of $1500-1200 \mathrm{~cm}^{-1}$ are sensitive to chemical and molecule structural transformations. The IR bands in the region of $1000-1200 \mathrm{~cm}^{-1}$ are connected with stretching $\mathrm{C}-\mathrm{O}-\mathrm{C}$ and $\mathrm{C}-\mathrm{O}$ vibrations. The IR peak in the region of $847 \mathrm{~cm}^{-1}$ characterizes the $\beta-1,4$ bonds vibrations. The BC FTIR spectra in different experiments practically do not change.

As known, immobilization is a technique used to trap the cells into a matrix. The aim of this stage was using immobilized cells for the fermentation of $\mathrm{BC}$ repeatedly. There is a data about using of immobilized cells of Acetobacter xylinum for the production of nata de coco is one alternative to the product resulted in a cell-free nata. From the results obtained that immobilized cell still produced nata up to two replications fermentation (Nugroho, Pradipta 2015). Our investigation was demonstrated that during the static cultivation regime using immobilized cells in a cryogel the BC is formed film on the surface of the medium, and during dynamic regime - in form of "stars" in small cellulose flakes. Using the FTIR the molecular structure of BC obtained with help of immobilized cells during dynamic and static culture 
conditions regime were the same. In next experiment we use RS for studies changes of the degrees of crystallinity BC production with the help of immobilized Gluconacetobacter sucrofermentans cells; the degree of crystallinity of the $\mathrm{BC}$ was lower than in $\mathrm{BC}$ from native cells of producers. X-ray diffractogram investigations indicated that majority of the cellulose synthesized as by native also by immobilized culture was type-1 $\beta$ cellulose what typical for Gluconacetobacter sp.

So, in the course of this study, the changes of the bacterial cellulose yields of were revealed during bacterial cultivation in a medium containing molasses with ascorbic acid and when we use immobilization of producer.

\section{Declarations}

\section{Ethics approval and consent to participate}

This article does not contain any studies with human participants or animals performed by any of the authors.

\section{Consent for publication}

The authors agree to publish their article

\section{Availability of data and materials}

All data are fully available without restriction.

\section{Competing interests}

The authors declare that they have no conflict of interest

\section{Funding}

The authors are grateful for the support of the Russian Foundation for Basic Research (project number 18-29-05054).

\section{Authors' contributions}

Revin V conceived and designed research. Atykyan N and Shutova V conducted experiments. Atykyan N contributed new methods of microorganism immobilization. Atykyan $\mathrm{N}$ and Shutova $\mathrm{V}$ analyzed data. Atykyan $\mathrm{N}$ wrote the manuscript. All authors read and approved the manuscript.

\section{References}

Augimeri RV, Varley AJ, Strap JL (2015) Establishing a role for bacterial cellulose in environmental interactions: lessons learned from diverse biofilm-producing proteobacteria. Front Microbiol 6:1282 
https://dx.doi.org/10.3389/fmicb.2015.01282

Brett C, Waldron K (1990) Physiology and biochemistry of plant cell wall. Topics in plant physiology. Springer, Netherlands https://doi.org/10.1007/978-94-010-9641-6

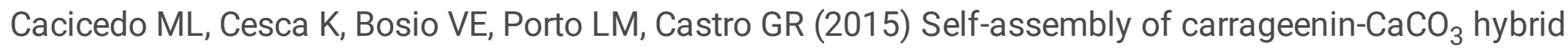
microparticles on bacterial cellulose films for doxorubicin sustained delivery. J Appl Biomed 13:239-248 http://dx.doi.org/10.1016/j.jab.2015.03.004

Cauerhff A, Castro GR (2013) Bionanoparticles, a green nanochemistry approach. Electronic J Biotech 16(3): 717-3458 https://dx.doi.org/10.2225/vol16-issue3-fulltext-3

Chawla PR, Bajaj IB, Shrikant AS, Singhal RS (2009) Microbial cellulose: fermentative production and application. Food Technol Biotechnol 47(2):107 - 124

https://ru.scribd.com/document/213780963/2058-Chawla-1-1 Accessed 28 February 2020

Coban E, Biyik P (2011) Evaluation of different pH and temperatures for bacterial cellulose production in HS medium and beet molasses medium. Afr J Microbiol Res 5(9);1037-1045

https://doi.org/10.5897/AJMR11.008

Fu L, Zhang J, Yang G (2013) Present status and applications of bacterial cellulose-based materials for skin tissue repair. Carbohydr Polym 92:1432-1442 https://dx.doi.org/10.1016/j.carbpol.2012.10.071

Guo X, Cavka A, Jönsson L (2013) Comparison of methods for detoxification of spruce hydrolysate for bacterial cellulose production. Microb Cell Fact 93(12):17『21 https://doi.org/10.1186/1475-2859-12-93

Hestrin S, Schramm M (1954) Synthesis of cellulose by Acetobacter xylinum. II. Preparation of freezedried cells capable of polymerizing glucose to cellulose. Biochem J 58(2):345 \ 346

https://www.ncbi.nlm.nih.gov/pmc/articles/PMC1269899/pdf/biochemj01080-0172.pdf Accessed 28 February 2020

Hsieh YC, Yano H, Nogi M, Eichhorn SJ (2008) An estimation of the Young's modulus of bacterial cellulose filaments. Cellulose 15(4):507-513 https://dx.doi.org/10.1007/s10570-008-9206-8.

Hungund B, Prabhu S, Shetty C, Acharya S, Prabhu V, Gupta SG (2013) Production of bacterial cellulose from Gluconacetobacter persimmonis $\mathrm{GH}-2$ using dual and cheaper carbon sources. J Microb Biochem Technol 5(2):31-33 http://doi.org/10.4172/1948-5948.1000095

Jozala AF, Pértile RA, Santos CA., Santos-Ebinuma VC, Seckler MM, Gama FM, Pessoa JrA (2014) Bacterial cellulose production by Gluconacetobacter xylinus by employing alternative culture media. Appl Microbiol Biotechnol 1:4区8 https://doi.org/10.1007/s00253-014-6232-3

Kaewnopparat S, Sansernluk K, Faroongsarng D (2008) Behavior of freezable bound water in the bacterial cellulose produced by Acetobacter xylinum an approach using thermoporosimetry. AAPS Pharm 
Sci Tech 9(2):701-707 http://dx.doi.org/10.1208/s12249-008-9104-2

Keshk S, Sameshima K (2006) The utilization of sugar cane molasses with/without th e presence of lignosulfonate for the production of bacterial cellulose. Appl Microbiol Biotechnol 72: 291-296 https://doi.org/10.1007/s00253-005-0265-6

Keshk S (2014a) Vitamin C enhances bacterial cellulose production in Gluconacetobacter xylinus. Carbohydr Polym 99:98-100 http://dx.doi.org/10.1016/j.carbpol.2013.08.060

Keshk S (2014b) Bacterial cellulose production and its industrial applications. J Bioprocess Biotech 4(2):150 http://dx.doi.org/10.4172/2155-9821.1000150

Kiziltas EE, Kiziltas A, Gardner DJ (2015) Synthesis of bacterial cellulose using hot water extracted 10 wood sugars. Carbohydr Polym 21(3):16-21 https://doi.org/10.1016/j.carbpol.2015.01.036

Klemm D, Schumann D, Udhardt U, Marsch D (2001) Bacterial synthesized cellulose-artificial blood vessels for microsurgery. Prog Polym Sci 26:1561-1603 https://dx.doi.org/10.1016/S00796700(01)00021-1

Kongruang S (2008) Bacterial cellulose production by Acetobacter xylinum strains from agricultural waste products. Appl Biochem Biotechnol 148:245-256 https://doi.org/10.1007/s12010-007-8119-6

Lee KY, Buldum G, Mantalaris A, Bismarck A (2014) More than meets the eye in bacterial cellulose: biosynthesis, bioprocessing, and applications in advanced fiber composites. Macromol biosci 14:10-32 https://dx.doi.org/10.1002/mabi.201300298

Lin D, Lopez-Sanchez P, Li R (2014) Production of bacterial cellulose by Gluconacetobacter hansenii CGMCC 3917 using only waste beer yeast as nutrient source. Bioresource Technol 151:113-119 https://doi.org/10.1016/j.biortech.2013.10.052

Maneerung T, Tokura S, Rujiravanit R (2008) Impregnation of silver nanoparticles into bacterial cellulose for antimicrobial wound dressing. Carbohydr Polym 72:43-51

https://dx.doi.org/10.1016/j.carbpol.2007.07.025

Masaoka S, Ohe T, Sakota N (1993) Production of cellulose from glucose by Acetobacter xylinum. J Ferment Bioeng 75:18-22 https://doi.org/10.1016/0922-338X(93)90171-4

Matsuoka MA, Tsuchida T, Matsushita K, Adachi O, Yoshinaga F (1996) A synthetic medium for bacterial cellulose production by Acetobacter xylinum subsp. sucrofermentans. Biosci Biotech Biochem 60(4):575579 https://doi.org/10.1271/bbb.60.575

Nugroho D, Pradipta A (2015) Characterization of nata de coco produced by fermentation of immobilized Acetobacter xylinum. Agriculture and Agricultural Science Procedia. 3:278-282 https://doi.org/10.1016/j.aaspro.2015.01.053 
Pa'e N, Zahan KA, Muhamad II (2011) Production of biopolymer from Acetobacter xylinum using different fermentation methods. Int J Eng Technol 11(5):90-98

https://pdfs.semanticscholar.org/56c8/8c6b3cedbda1616c0c6ab23db70be802ba17.pdf Accessed 28 February 2020

Park JK, Jung JY, Park PY (2003) Cellulose production by Gluconacetobacter hansenii in a medium containing ethanol. Biotechnology letters 25:2055-2059

https://doi.org/10.1023/B:BILE.0000007065.63682.18

Ramana KV, Tomar A, Singh L (2000) Effect of various carbon and nitrogen sources on cellulose synthesis by Acetobacet xylinum. World J Microbiol Biotechnol 16:245 - 248 https://doi.org/10.1023/A:1008958014270

Rani MU, Appaiah KAA (2013) Production of bacterial cellulose by Gluconacetobacter hansenii UAC09 using coffee cherry husk J Food Sci Technol. 50(4):755-762 https://doi.org/10.1007/s13197-011-0401-5

Rastogi A, Singh J, Das M, Kundu D, Banerjee R (2018) An understanding of bacterial cellulose and its potential impact on industrial applications. In Principles and applications of fermentation technology (eds Kuila A, SharmaV) https://dx.doi.org/10.1002/9781119460381.ch20

Revin VV, Kostina EG, Revina NV, Shutova VV (2018) Effect of nutrient sources on the alginate accumulation in the culture liquid of Azotobacter vinelandii D-05 and obtaining biocomposite materials. Braz Arch Biol Technol 61: e18160406 http://dx.doi.org/10.1590/1678-4324-2018160406

Revin VV, Shutova VV (2015) Adhesives on the base of modified Leuconostoc mesenteroides cultural fluid. J Biotech 208: S116 http://dx.doi.org/10.1016/j.jbiotec.2015.06.367

Revin VV, Shutova VV, Novokuptsev NV (2016) Biocomposite materials from lignocellulose raw materials and levan produced by Azotobacter vinelandii. J Biotech 231: S8

http://dx.doi.org/10.1016/j.jbiotec.2016.05.055

Schenzel K, Fischer S (2004) Applications of FT Raman spectroscopy for the characterization of cellulose. Lenzinger Berichte 83:64-70

https://pdfs.semanticscholar.org/5cd5/648c6f5839be5f89fbc1e910a32e1cdb3870.pdf Accessed 28 February 2020

Schenzel K, Fischer St, Brendler E (2005) New method for determining the degree of cellulose I crystallinity by means of FT Raman spectroscopy. Cellulose 12:223-231 https://doi.org/10.1007/s10570-004-3885-6

Son HJ, Kim HG, Kim KK, Kim SH, Kim YG, Lee SJ (2003) Increased production of bacterial cellulose by Acetobacter sp. V6 in synthetic media under shaking culture conditions. Bioresour Technol 86:215-219 http://dx.doi.org/10.1016/S0960-8524(02)00176-1 
Szymańska-Chargot M, Cybulska J, Zdunek A (2011) Sensing the structural differences in cellulose from apple and bacterial cell wall materials by Raman and FT-IR Spectroscopy. Sensors 11(6):5543-5560 http://dx.doi.org/10.3390/s110605543

Thompson DN, Hamilton MA (2001) Production of bacterial cellulose from alternate feedstocks. In Davison BH, McMillan J, Finkelstein M (eds) Twenty-Second Symposium on Biotechnology for fuels and chemicals. ABAB Symposium. Humana Press, Totowa, NJ https://doi.org/10.1007/978-1-4612-02172_43

Wu J-M, Liu R-H (2013) Cost-effective production of bacterial cellulose in static cultures using distillery waste water. J Biosci Bioengin 115(3):284-290 https://doi.org/10.1016/j.jbiosc.2012.09.014

Zeng X, Small DP, Wan W (2011) Statistical optimization of culture conditions for bacterial cellulose production by Acetobacter xylinum BPR 2001 from maple syrup. Carbohydr Polym 85:506-513 https://doi.org/10.1016/j.carbpol.2011.02.034

Zhu H, Jia S, Wan T, Jia Y, Yang H, Li J, Yan L, Zhong C (2001) Biosynthesis of spherical $\mathrm{Fe}_{3} \mathrm{O}_{4} /$ bacterial cellulose nanocomposites as adsorbents for heavy metal ions. Carbohydr Polym 86(4):1558-1564 https://dx.doi.org/10.1016/j.carbpol.2011.06.061

Zugenmeier P. (2008) Crystalline cellulose and derivatives. Characterization and structure. Springer-Verlag Berlin Heidelberg

\section{Figures}




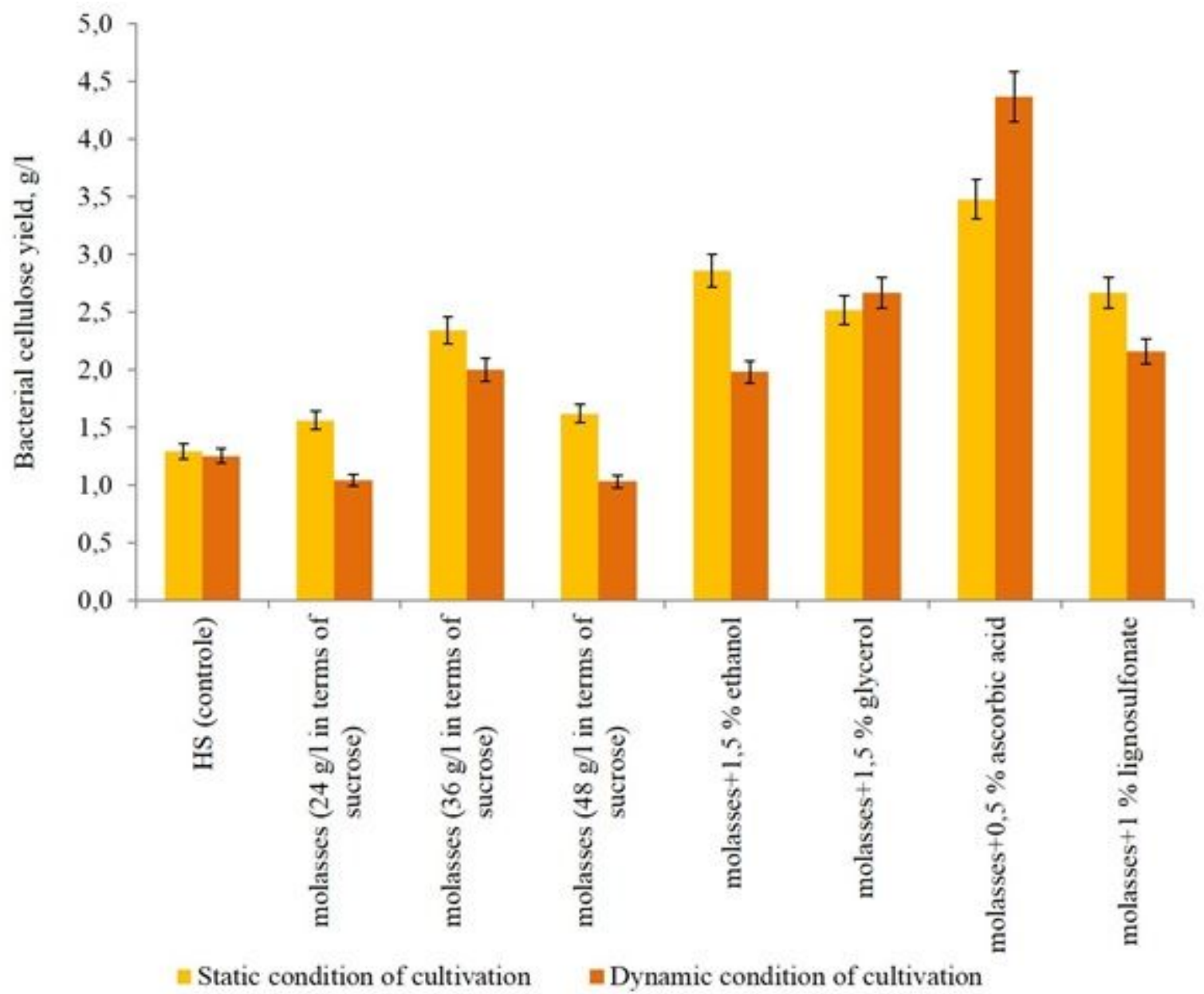

Figure 1

Yield of bacterial cellulose under static and dynamic condition of cultivation on various medium 


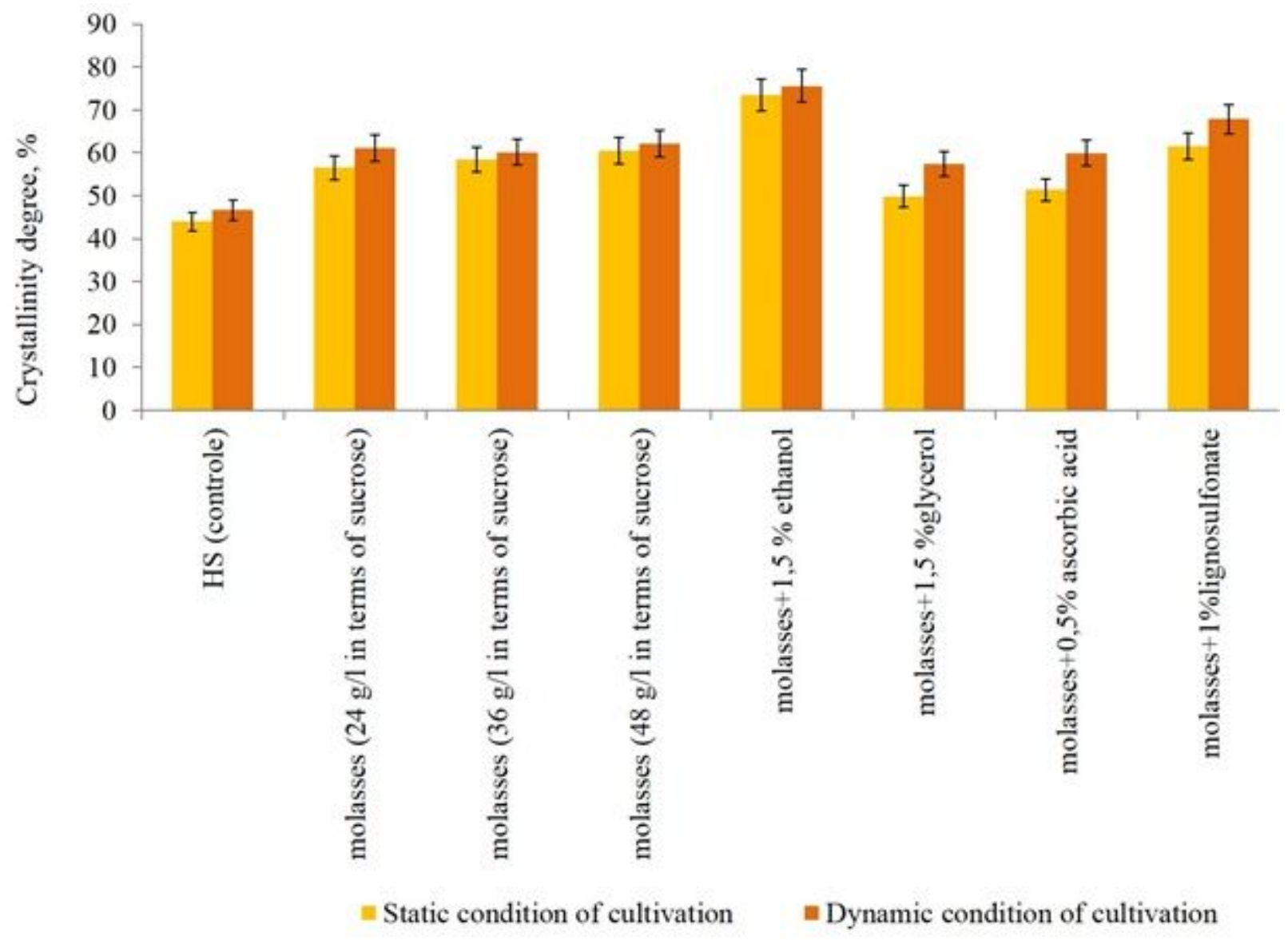

Figure 2

Crystallinity degree of bacterial cellulose obtained in static and dynamic condition of cultivation on various medium 


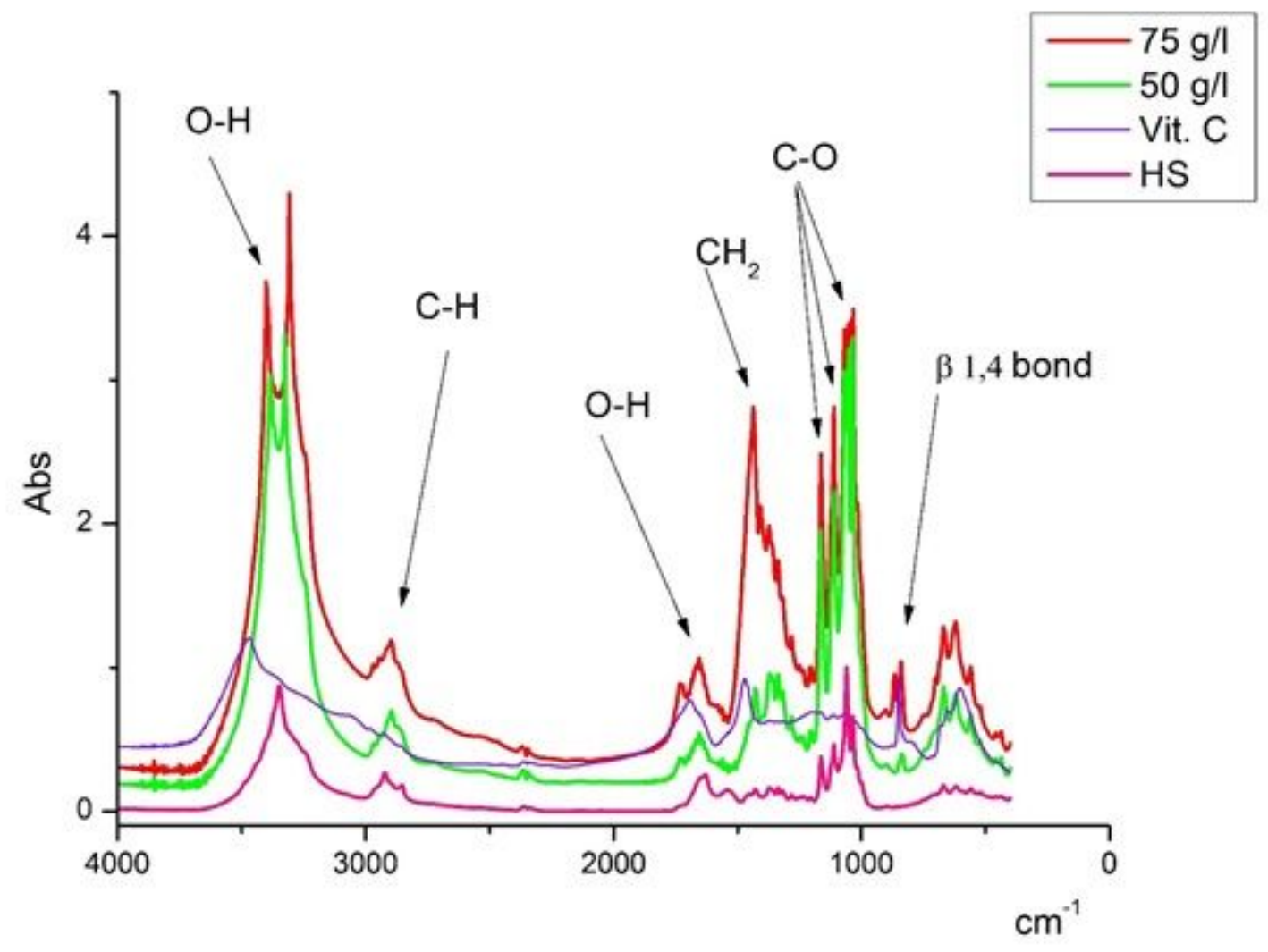

Figure 3

FTIR spectra of bacterial cellulose obtained in static and dynamic condition of cultivation on various medium 


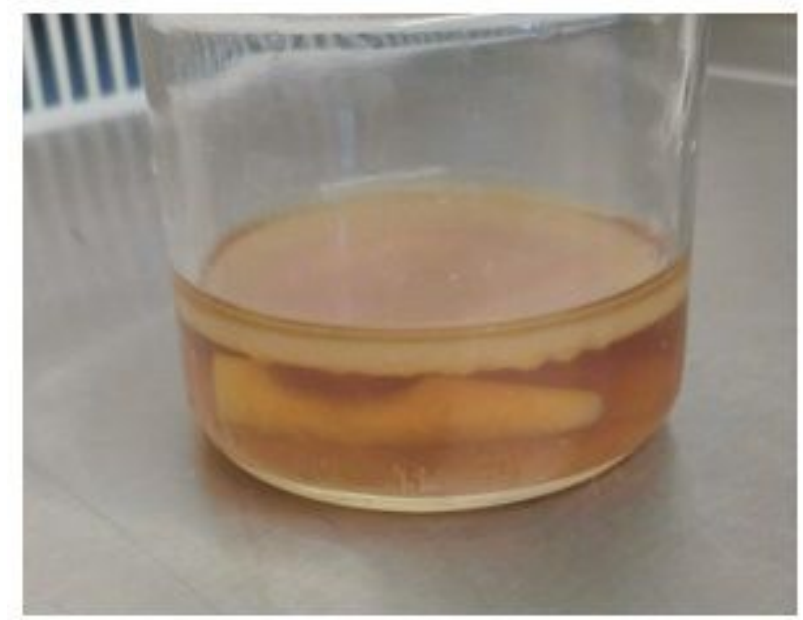

A

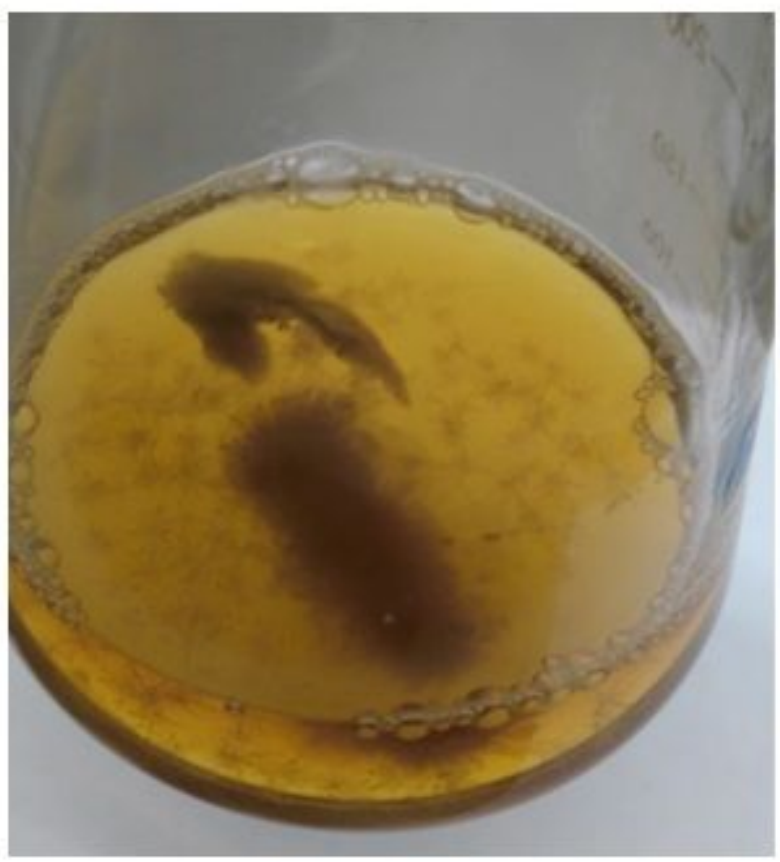

B

Figure 4

Immobilized cells producing bacterial cellulose (HS medium): A - static conditions of cultivation, B dynamic conditions of cultivation 


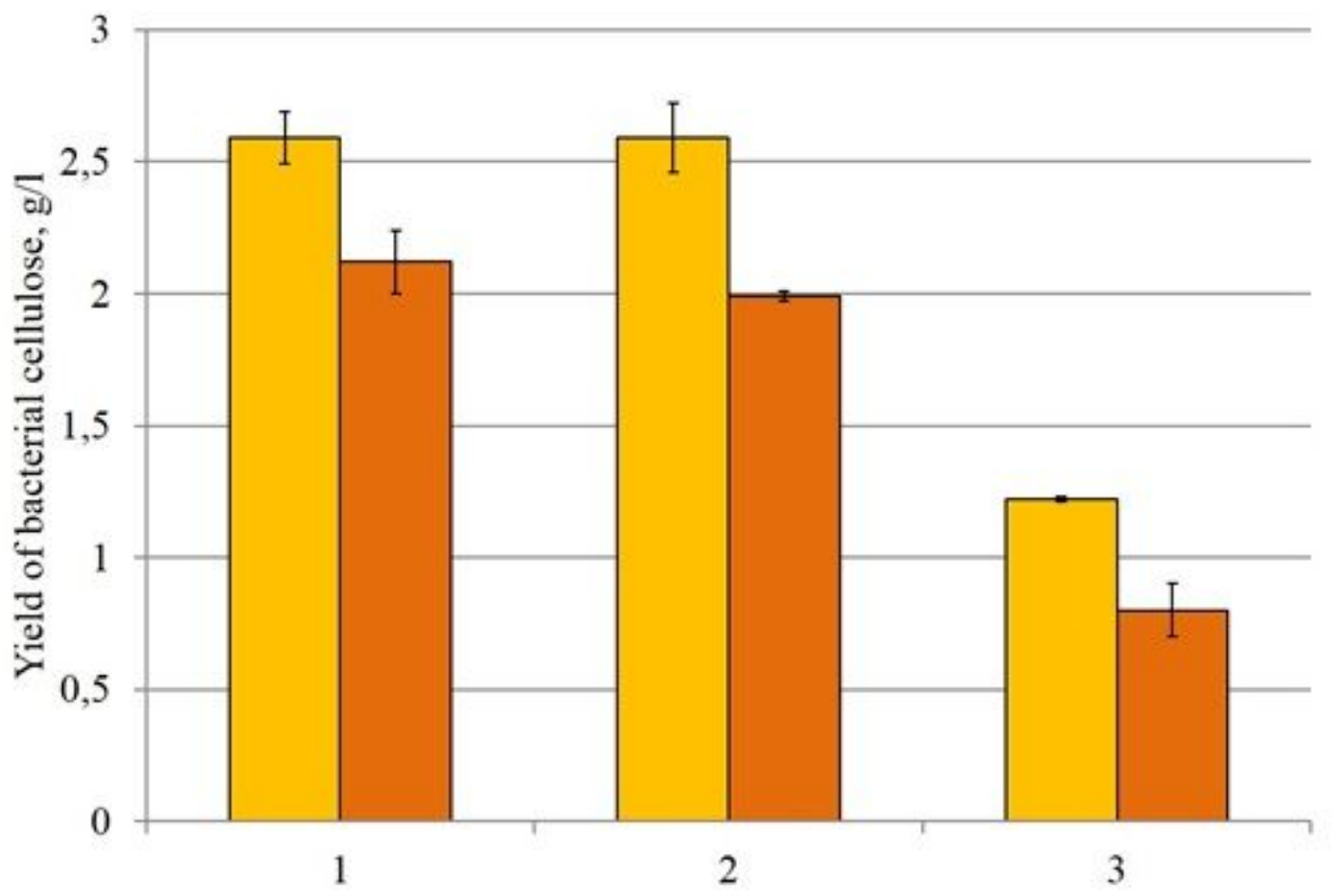

- Dynamic condition of cultivation

- Static condition of cultivation

\section{Figure 5}

The yield of bacterial cellulose obtained in static and dynamic conditions of semi-continuous cultivation using immobilized cells 


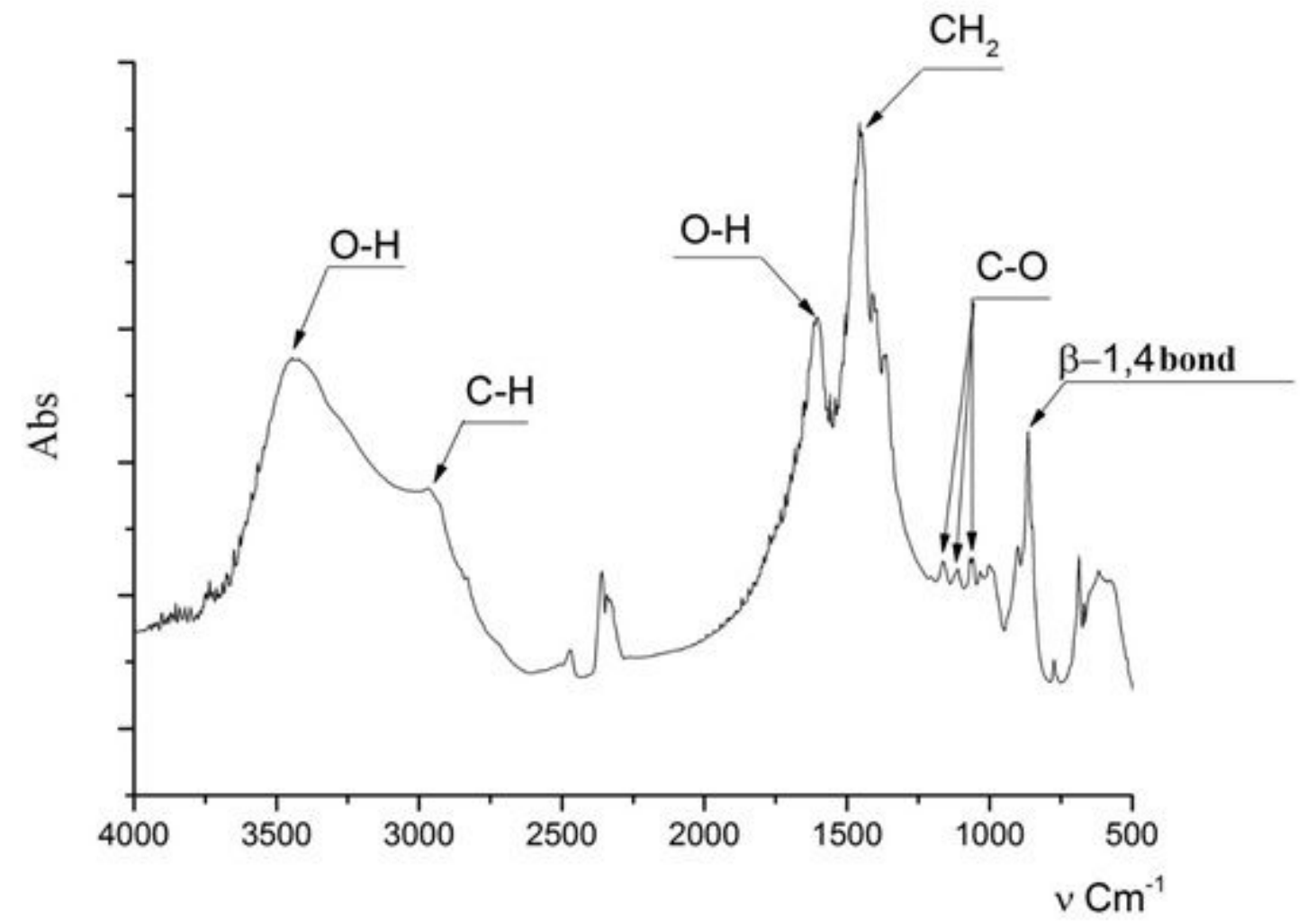

Figure 6

FTIR spectrum of bacterial cellulose obtained under dynamic conditions on a molasses medium using producer immobilized cells 

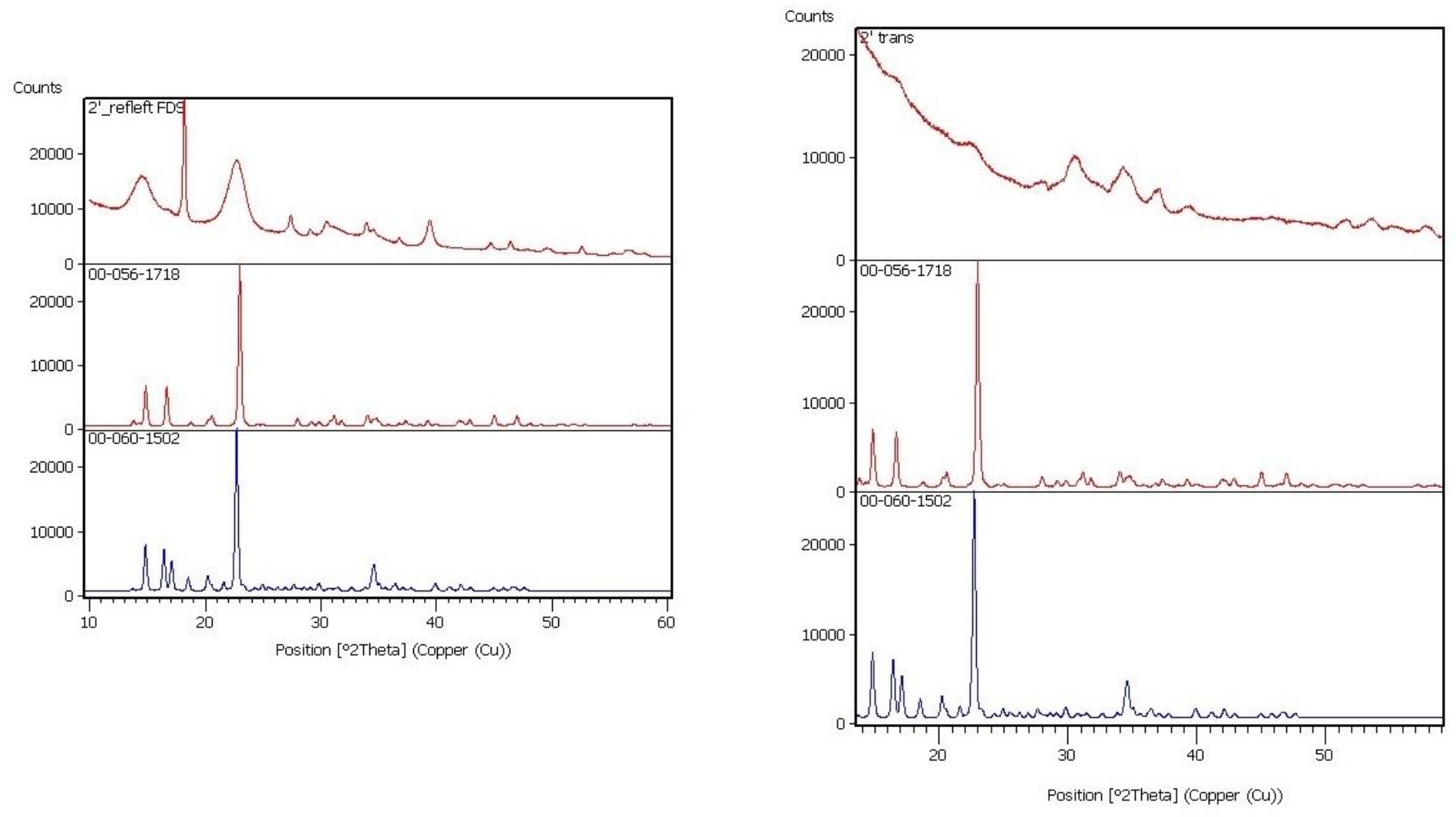

\section{Figure 7}

$X$ - ray diffractogram obtained from the $\mathrm{BC}$ sample (measurements were carried out in two setups: "reflection" (A) and "transparency" (B)). 


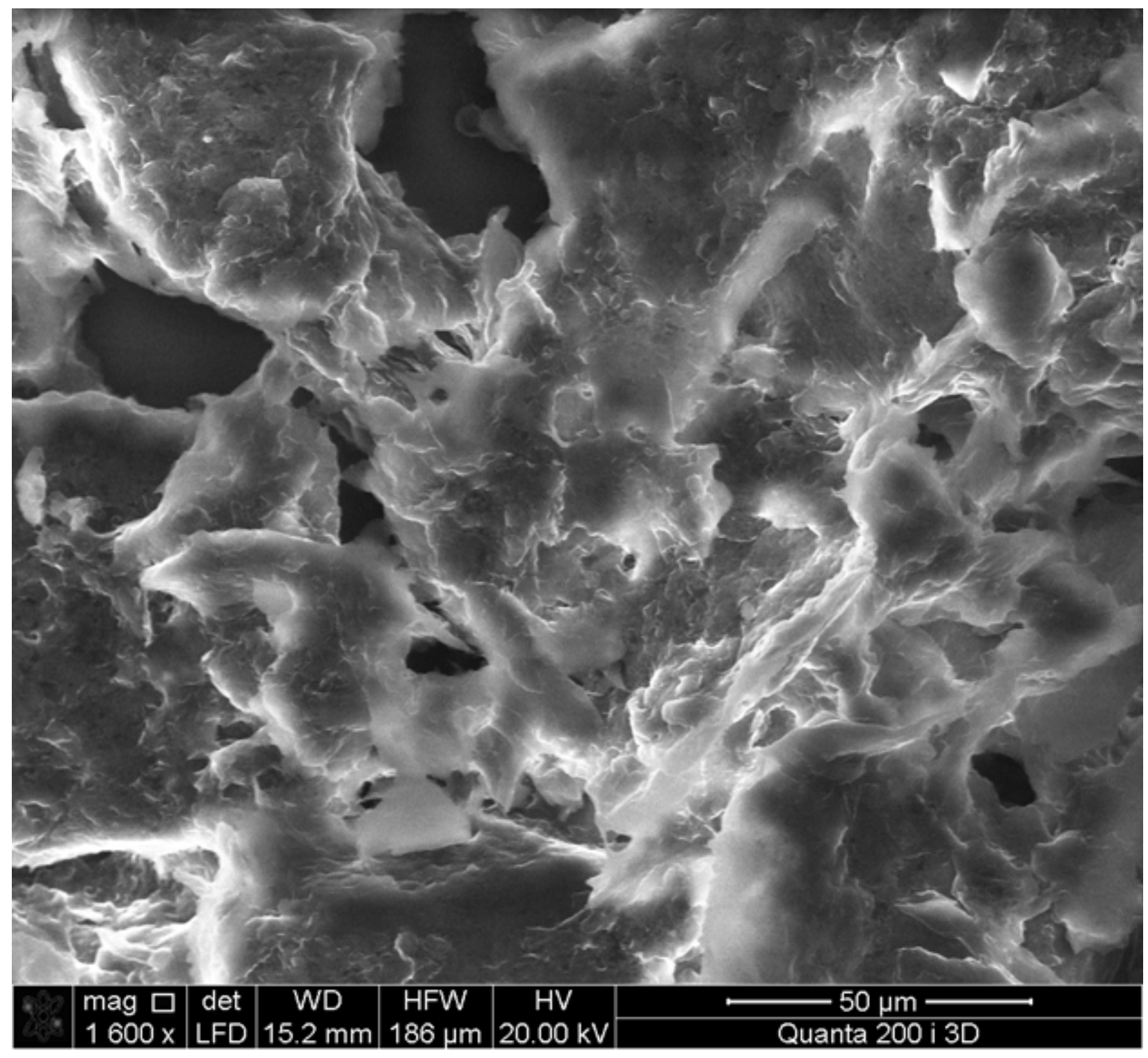

Figure 8

SEM images of dried flakes of bacterial cellulose synthesized by immobilized culture 